\author{
Katarzyna Mamcarz \\ Maria Curie-Sklodowska University in Lublin \\ e-mail: katarzyna.mamcarz@poczta.umcs.lublin.pl \\ ORCID: 0000-0001-9195-3410
}

\title{
ANALYSIS OF GRANGER CAUSALITY BETWEEN GOLD AND SELECTED FINANCIAL ASSETS
}

DOI: $10.15611 / \mathrm{pn} .2020 .7 .06$

JEL Classification: G1, G15, C32

(C) 2020 Katarzyna Mamcarz

This work is licensed under the Creative Commons Attribution-ShareAlike 4.0 International License. To view a copy of this license, visit http://creativecommons.org/licenses/by-sa/4.0/

Quote as: Mamcarz, K. (2020). Analysis of Granger causality between gold and selected financial assets. Prace Naukowe Uniwersytetu Ekonomicznego we Wrocławiu, 64(7).

\begin{abstract}
Gold belongs among the assets which show low or negative correlations with the markets for fundamental financial assets, and can serve as an alternative form of capital investment. Therefore, it becomes material to assess the impact of these markets on the gold market (prices), and the correlations existing between them. Investors' decisions to allocate capital in these markets determine the kind and direction of causation between the assets in question. The aim of this article is to assess the causality between the rates of return on investments in gold and in the following assets: stocks, bonds, and real estate, represented by the corresponding market indices. The research covered the period 1997-2018. The analysis employed the VAR model to test linear Granger (non)causality and the variance decomposition. Apart from two cases of unidirectional causality, i.e. from bond returns to gold, and from gold returns to real estate, no other types of causality occurred, which except for these cases, implies that changes in gold prices did not impact on investors' decisions of engaging capital on other analyzed markets, and vice versa.
\end{abstract}

Keywords: stock, bond and real estate markets, gold price, VAR models, Granger causality.

\section{Introduction}

The aim of this article is to assess the causal relations between the ROR from investments in gold and the ROR from investments in the three fundamental assets, i.e. stocks, bonds and real estate, represented by the market indices Standard \&Poor's 500 Index (S\&P500), Bloomberg Barclays US Agg Total Return Value Unhedged USD (LBUSTRUU), and the US Wilshire Real Estate Investment Trust Index (WILREIT). 
Gold belongs among the assets which show low or negative correlations with the financial markets in question, and can serve as an alternative form of capital investment. Therefore, it becomes material to assess the impact of these markets on the gold market (prices), and the correlations existing between them. The low rates of return on these markets, and in particular stock market crashes, make investors more inclined to re-invest in gold as a relatively safe option, while the growing prices of the assets under consideration lead to reduced interest in this precious metal. Investors' decisions to allocate capital to these markets determine the kind and direction of causation between the assets. The following research hypothesis was formulated. The ROR on the financial markets in question accounts for the Granger causality of the ROR on the gold market.

The analysis employed the VAR model forming the basis for testing linear Granger (non)causality, along with variance decomposition. Basic descriptive statistics and a descriptive analysis were used in the research. The research was conducted by analysing data for the period 1997-2018.

\section{Literature review}

The correlations between various groups of assets, including gold, have been analysed by many authors. However, these analyses were initially limited to the strength and directions of such correlations, and they concerned various countries and geographical regions. Consequently, the authors' focus was on analysing the causal relations between the variables of interest, using vector autoregression (VAR) models, along with Granger causality based on reduced-form VAR. Some authors extended their research by analysing forecast error variance decompositions and impulse-response functions.

Ling (1998), based on monthly data for the period 1972-1995, analysed the correlations between the stock prices of Equity Real Estate Investment Trusts (EREIT) and Mortgage Real Estate Investment Trusts (MREIT), by means of cointegration and causality tests. He applied an error correction model (ECM) estimate, claiming that there was a long-run permanent linear relationship between these variables resulting from their typical reaction to market changes in ROR, interest rates, and other factors. The Geweke causality test indicated a causal relation from EREIT to MREIT, additionally implying a general linear relationship, and a direct linear bidirectional causality between EREIT and MREIT changes. The results obtained for the vector error correction model (VECM) not only revealed a significant improvement in the quality of the model when compared to the VAR model, but also showed the equilibrium REIT market price in the long run.

Zhang and Wei (2010) analysed the cointegration and causal relations between the gold market and the crude oil market. Their findings revealed a significant positive correlation between the two markets in the period from January 2000 to March 2008, and their long-run equilibrium. Crude oil prices were found to Granger- 
cause the level of gold prices, but not the other way round, and only in the case of linear interdependences.

Sujit and Kumar Rajesh (2011) analysed the correlations between gold prices, stocks (S\&P500), exchange rates, and crude oil prices (WTI, BRENT) in the period from 2 January 1998 to 5 June 2011, by means of VAR and cointegration analyses. The authors employed the two models taking into account the gold price (USD), the WTI, the exchange rate, the S\&P and Brent Indices, the exchange rate, the WTI, and the gold price (EUR), respectively. They found that the exchange rate significantly influenced the other variables, whereas stocks had a lesser impact on the exchange rate. One of the models (model 2) revealed a weak long-run interdependence between the variables under consideration. The authors also analysed the impulse-response function and the variance decomposition.

Wang and Chueh (2013) dealt with short and long-run correlations between interest rates, crude oil prices, gold prices, and the exchange rate of the U.S. dollar. The analysis covered the period from 2 January 1998 to 20 December 2007, and the models employed for its purpose included the Threshold Cointegration Model (TCM) and the Threshold Error Correction Model (TECM). The prices of gold and crude oil were found to be positively correlated in the short run. The authors revealed the impact of interest rate changes on gold prices, and found that interest rates negatively influenced the prices of gold futures, contrary to crude oil prices, whose impact was positive.

Singh (2014) analysed the causal relations between the stock market index, gold, and crude oil in India. He performed the Johansen cointegration and Granger causality tests, and analysed the stationary character of time series by means of the Augmented Dickey-Fuller (ADF) test and the Phillips-Perron (PP) test. The Granger test revealed unidirectional causality between the stock market index and the price of gold, and between the price of crude oil and the stock index. The interdependence between the assets under analysis was found to be positive.

Acikalin and Bayci (2016) focused on the relationship between two Istanbul Stock Exchange indices, i.e. the BIST Gold Market Index (GOLD) and the Istanbul Stock Exchange National 100 Index (BIST 100) in the period from 1 August 2012 to 17 March 2015, using daily quotes for these indices. They employed the following methods: the Augmented Dickey Fuller test, the Engle-Granger cointegration test, the ECM, and the Granger causality test. They found that the BIST 100 and GOLD indices were cointegrated, which implies a long-run equilibrium between them. The Granger causality test confirmed a unidirectional causal interdependence between the BIST 100 and GOLD in the analysed period.

Bouri, Jain, Biswal and Roubaud (2017) analysed the correlations between the global market for gold and crude oil, and the Indian stock market, between June 2009 and May 2016. The authors made use of the Gold Volatility Index (GVZ), the Crude Oil Volatility Index (OVX), and the Volatility Index for the NIFTY Indian Stock Market (the Indian VIX), with a view to analysing the cointegration and non-linear causality between the said markets. Their findings indicated a cointegration 
relationship and a non-linear positive influence by the implied volatility of gold and crude oil on the stock market under consideration. The authors also stressed the occurrence of two-way reverse causality between the implied volatility of gold and crude oil prices.

Fernandez-Perez, Frijns and Tourani-Rad (2017) dealt with the correlations between precious metals, crude oil, and the exchange rate of the U.S. dollar between 1 November 1996 and 31 December 2015. According to the authors, the reduced-form vector autoregressive VAR model failed to accurately reflect the interactions between the variable series under analysis, as it overlooked the effects occurring simultaneously. These could be captured by means of the structural VAR model (referred to as SVAR). In their investigations, the authors also employed the IRF analysis. As regards precious metals, they found no Granger causality. However, they identified simultaneous interdependencies which were of various intensities, depending on the direction of the mutual impact of the variables. No such relations were found from crude oil to metal.

Tursoy and Faisal (2018) dealt with interactions between the prices of stocks, gold, and crude oil, both in the long and short run, based on monthly data covering the period from January 1986 to November 2016 on the Turkish market, using the Autoregressive Distributed Lag Model (ARDL). Their findings proved a negative interdependence between the prices of gold and stock, and a positive interdependence between the prices of crude oil and stocks, again in both the long and short run. Nonetheless, the Granger causality test revealed simultaneous and unidirectional causality, in both the long and short run, from gold prices to stock prices.

Singh and Sharma (2018) analysed the cointegration and causal relations between gold, the exchange rate of the U.S. dollar, and the stock market (the Sensex index) during the global financial crisis of 2008, using the Johansen cointegration test, the VCEM and VAR models, the Granger causality test, and variance decomposition, to examine the cointegration, strength and direction of causation in three sub-periods, i.e. before, during and after the crisis. The Granger test revealed unidirectional causality from the dollar and the Sensex index to crude oil, and from gold and the Sensex index to the dollar. They also showed that the relationship between these variables was dynamic and had been brought in by the global financial crisis in 2008 .

\section{Research methodology}

The Granger causality analysis was carried out using two-dimensional VAR(p) models in their standard form (reduced-form VAR models) (Enders, 2010, pp. 325-327; Kusideł, 2000, pp. 16, 34):

$$
x_{t}=A_{0} D_{0}+\sum_{i=1}^{p} A_{p} x_{t-p}+e_{t},
$$


where: $x_{t}=\left[y_{t}, z_{t}\right]^{\prime}-$ vector of variables, $y_{t}$ - the first-differences of logarithms of index value, $z_{t}$ - the first-differences of logarithms of gold price, $D_{0}$ - vector of deterministic components, $A_{0}=B^{-1} \Gamma_{0}$ - the matrix for model constants, $A_{i}=B^{-1} \Gamma_{\mathrm{i}}$ - the matrix for the parameters with lagged variables of vector $x_{t}$, $e_{t}=B^{-1} \varepsilon_{t}-$ the stationary random-noises vector, $B$ - matrix of the structural model parameters for non-lagged variables.

The number of lags ( $p$ ) for the estimated models was determined on the basis of the Akaike information criterion (AIC), the Bayesian information criterion (BIC), and the Hannan-Quinn information criterion (HQC).

Models were estimated on the basis of first-differences of logarithms reflecting the rates of return (ROR) from investment in the analysed assets without an ECM component. This was justified by the results of the analysis of cointegration between variables which was carried due to the fact that the input series of logarithms presented the first-order of integration (the ADF test). In such cases the inclusion of ECM should be considered to express the long-run relationship between non-stationary variables for models estimated on the basis of first differences of variables. The Engle-Granger procedure (the ADF test for residuals), and the Johansen test, were performed to answer this question. A null hypothesis, assuming that the VAR model had no cointegration vectors (H0: $r=0$ ), was tested against an alternative hypothesis, H1: $r \leq 1$ (Johansen and Juselius, 1990; Charemza and Deadman, 1997, p. 129, 165; Kusideł, 2000, pp. 45-46, 58). The correlation coefficients for variable increments were also analysed with a view to eliminating any spurious regression.

The Granger causality test was carried out to analyse causal relations, with the aim of verifying whether variable $\mathrm{z}$ Granger-caused variable $y(z \rightarrow y)$. Attempts were made to verify whether the current values of $\mathrm{z}$ could be projected with better precision on the basis of previous values of $\mathrm{z}$, as compared to a situation where the latter was not included in the model, assuming that the remaining information was not subject to change. The reverse correlation $(y \rightarrow z)$ was also investigated (Charemza, and Deadman 1997, p. 158).

The F-test was conducted according to the following formula (Gujarati, 2003, pp. 697-698):

$$
F=\frac{\left(R S S_{R}-R S S_{U R}\right) / m}{R S S_{U R} /(n-k)},
$$

where: $R S S_{R}$ - the residual sum of squares for the model exhibiting certain limitations, i.e. not including the lagged values of variable $z_{t}$, but only the lagged values of variable $y_{t,}$ and possibly of other variables, where applicable; $R S S_{U R}$ - the residual sum of squares for the model with no limitations; $m$ - the number of lags of variable $z_{t}$ based on AIC or BIC; $k$ - the number of parameters estimated in the model with no limitations. 
The statistics exhibit an F-distribution with $\mathrm{m}$ and $(n-k)$ degrees of freedom. The same procedure could be conveniently performed in respect of the reverse relationship, each time assuming that the variables were of a stationary nature.

With the aim of determining the correlations between the analysed variables in a more-precise manner, the Granger causality test was extended by analysing forecast-error variance decompositions to verify the results obtained in the causality test, as an auxiliary method to explore the interactions and structure of correlations between the variables under consideration.

In order to analyse variance decomposition, the standard-form model had to be transformed into a structural model, encompassing the so-called orthogonal innovations, i.e. model residuals not correlated to one another (shocks, distortions, random noises, impulses).

As regards the two-dimensional VAR(1) model, its structural form is (Enders, 2010, p. 298):

$$
B x_{t}=\Gamma_{0}+\Gamma_{1} x_{t-1}+\varepsilon_{t},
$$

where the vector of constant values for the equations in model $\left(\Gamma_{0}\right)$ and the matrices $\left(B, \Gamma_{1}\right)$ of the structural model parameters with the appropriate variables (both nonlagged and lagged), as well as observation vectors $\left(x_{t}\right)$ and random noises (shocks) $\left(\varepsilon_{t}\right)$, can be defined as

$$
B=\left[\begin{array}{cc}
1 & b_{12} \\
b_{21} & 1
\end{array}\right] ; \Gamma_{0}=\left[\begin{array}{l}
b_{10} \\
b_{20}
\end{array}\right] ; \Gamma_{1}=\left[\begin{array}{ll}
\gamma_{11} & \gamma_{12} \\
\gamma_{21} & \gamma_{22}
\end{array}\right] ; x_{t}=\left[\begin{array}{l}
y_{t} \\
z_{t}
\end{array}\right] ; \varepsilon_{t}=\left[\begin{array}{l}
\varepsilon_{y t} \\
\varepsilon_{z t}
\end{array}\right] .
$$

The structural VAR model (a primitive system) cannot be directly estimated and is identifiable only if certain restrictions are imposed. The parameters of the standard-form model are estimated by means of the ordinary least squares (OLS) method for each equation separately, given that the regressors are not correlated with random elements. Moreover, the residuals obtained from the two regressions make it possible to estimate the variance of random elements $e_{1 t}$ and $e_{2 t}$, and their covariance (Enders, 2010, p. 305). To this end, the interdependence between the diagonal variance-covariance matrix for structural model noises, on the one hand, and the noise covariance matrix for the standard-form model, on the other, were used (Kusideł, 2000, p. 34; Enders, 2010, p. 330).

Having obtained the matrix B parameters through the Cholesky decomposition, the correlations between the random noises in the structural and standard-form models can be established using the formula (Enders 2010, pp. 326-327):

$$
\left[\begin{array}{l}
e_{1 t} \\
e_{2 t}
\end{array}\right]=\frac{1}{1-b_{12} b_{21}}\left[\begin{array}{cc}
1 & -b_{12} \\
-b_{21} & 1
\end{array}\right]\left[\begin{array}{l}
\varepsilon_{y t} \\
\varepsilon_{z t}
\end{array}\right] \text {. }
$$

This made it possible to determine the so-called structural innovations (shocks, distortions $-\varepsilon_{t}$ ) based on observable residuals $e_{t}$. 
The forecast error variance decomposition provides information on the extent to which changes in $y_{t}$ and $z_{t}$ are attributed to their own shocks, and the extent to which they are caused by shocks pertaining to the other variable.

When analysing the forecast error variance decomposition, it is essential to set the variable ordering, i.e. to determine which variable is the most exogenous (a priority variable) and which is the most endogenous (dependent on other variables). This procedure has a bearing on the overall quality of the research, as different orders of model equations (variables) are likely to influence the obtained results. For this reason it appears advisable to analyse all the possible ways of ordering the model equations in order to compare differences in the variance structure. The stronger the correlations between the residuals obtained through subsequent model equations, the stronger the differences in the obtained results (Enders 2010, p. 314, 315.). All calculations were performed in GRETL.

\section{Data sample}

The empirical research was based on data regarding the gold market, and on the markets of the three groups of assets under analysis, i.e. stocks, bonds, and real estate, represented by the S\&P500, LBUSTRUU, and WILREIT indices, respectively (monthly data as at the end of the month, for 1997-2018). The research covered a period of 21 years. The analysis included the logarithmic rates of return in monthly terms, determined on the basis of price quotations for gold and indices characteristic of the markets in question, the overall number of observations being 265. The empirical data for the indices were acquired from on-line portals, including Yahoo Finance, Ycharts, Bloomberg, and Wilshire Associates, and the prices of gold were taken from the World Gold Council.

Four time series, i.e. the price of gold and three market indices (S\&P500, LBUSTRUU, and WILREIT), were under investigation. The basic descriptive statistics used for the time series of the analysed variables are shown in Table 1.

Among the time series under analysis, the highest variability was displayed by WILREIT $(58.37 \%)$, followed by gold $(57.87 \%)$, S\&P500 (34.78\%), and LBUSTRUU, (30.34\%). All the explanatory variables satisfied the model analysis condition, as they exceeded the minimum required value of the coefficient of variation ( $\mathrm{V}>10.0 \%$ ). Three variables were characterised with right (positive) asymmetry, and only one exhibited left (negative) asymmetry (LBUSTRUU). Among these, only the S\&P500 exhibited a leptokurtic distribution, whereas the remaining values were characterised by weak concentration around the median, as compared to a normal distribution (a platykurtic distribution).

Of note is the fact that the research concerned a specific development period (1997-2018) on the gold market. Four sub-periods could be distinguished, i.e. (a) market stagnation, continuing until April 2001 (with the lowest gold price recorded on 2 April 2001, at USD 255.95/oz), followed by (b) an unprecedented market 
Table 1. The descriptive statistics of time series (LBUSTRUU, S\&P500, WILREIT and gold) in the period from 31.12.1996 to 31.12.2018

\begin{tabular}{|l|c|c|c|c|}
\hline \multicolumn{1}{|c|}{ Statistics/variable } & LBUSTRUU & S\&P500 & WILREIT & Gold \\
\hline Mean & 1412.40 & 1448 & 4802.50 & 826.83 \\
\hline Median & 1377.80 & 1301.80 & 4587.50 & 789.50 \\
\hline Min & 701.43 & 735.09 & 1344.00 & 254.80 \\
\hline Max & 2048.20 & 2914.00 & 10448.00 & 1813.50 \\
\hline Standard deviation & 428.58 & 503.61 & 2803.10 & 478.44 \\
\hline Coefficient of variation & 0.3034 & 0.3478 & 0.5837 & 0.5787 \\
\hline Skewness & -0.0102 & 1.1218 & 0.45288 & 0.25014 \\
\hline Kurtosis & -1.3698 & 0.4726 & -1.0411 & -1.3823 \\
\hline
\end{tabular}

Source: own work based on (World Gold Council [WGC], n.d.; Bloomberg, n.d.; Wilshire Associates, n.d.; Yahoo Finance, n.d.; YCharts, n.d.).

boom, continuing until early September 2011 (with the highest gold price recorded on 6 September 2011, at USD 1895.0/oz), then by (c) a sudden crash, which in effect continued until the end of 2015 (with the gold price at USD 1049.40/oz recorded on 17 December 2015), and then by (d) a period of market stabilisation (a sideways trend to the end of analysed period). As regards the remaining assets, their market developments were different when compared to gold, except in a few rather short periods. When the markets for other assets experienced crashes, gold was likely to serve as a viable alternative for investors. Further on in the analysis, logarithmic variables were employed, making it possible to transform non-linear relations into linear. The continuous rates of return so established were found to exhibit a closerto-normal distribution than discrete ROR, while still satisfying the conditions for the capital market models (Steiner, and Bruns 1996, p. 53).

The order of integration was tested for the analysed data using the ADF (Augmented Dickey-Fuller Unit Root Test), with AIC being employed in the lag selection process. The results are shown in Table 2.

Table 2. ADF test results for a series of logarithms in the period from 31.12.1996 to 31.12.2018

\begin{tabular}{|c|l|l|l|}
\hline \multirow{2}{*}{ I } & \multirow{2}{*}{ Index/price } & \multicolumn{1}{|c|}{ Variable } & \multicolumn{1}{c|}{ First difference } \\
\cline { 3 - 4 } & & \multicolumn{1}{|c|}{ tau statistic [p-value $]$} & \multicolumn{1}{c|}{ tau statistic $[\mathrm{p}$-value $]$} \\
\hline 1 & LBUSTRUU & $-2.87428[0.0484]$ & $-8.77745\left[2.318 \times 10^{-15}\right]$ \\
\hline 2 & S\&P500 & $-1.12356[0.7088]$ & $-14.8547\left[1.395 \times 10^{-26}\right]$ \\
\hline 3 & WILREIT & $-0.980794[0.7622]$ & $-6.82426\left[9.779 \times 10^{-10}\right]$ \\
\hline 4 & Gold & $-0.579679[0.8728]$ & $-18.2736\left[1.267 \times 10^{-29}\right]$ \\
\hline
\end{tabular}

Source: own work based on (World Gold Council [WGC], n.d.; Bloomberg, n.d.; Wilshire Associates, n.d.; Yahoo Finance, n.d.; YCharts, n.d.). 
The unit-root test results revealed that the analysed series were non-stationary, as the null hypothesis of the non-stationary character of the time series, at the significance level of $\alpha=0.01$, could not be rejected. However, as the first increments were of a stationary character, the series displayed the first order of integration I(1).

\section{Results}

\subsection{The Granger causality and cointegration analysis}

Based on the cointegration analysis conducted using the Engle-Granger method for logarithmic series (index, gold price) displaying the first order of integration I(1), the ADF $(\alpha=0.01)$ test results revealed that there were no grounds for rejecting the null hypothesis of the non-stationary character of the residuals obtained for the models representing linear combinations of these variables. Likewise, the Johansen cointegration test (the matrix trace test; the maximum eigenvalue test) also confirmed that the null hypothesis of there being no cointegration vectors in the VAR model (H0:r=0) could not be rejected, which reflected the absence of any long-run relationship between the pairs of variables under analysis. The corresponding results are compiled in Table 3.

Table 3. Engle-Granger's cointegration test and Johansen cointegration test

\begin{tabular}{|c|c|c|c|c|c|c|}
\hline \multirow[b]{2}{*}{ I } & \multirow{2}{*}{$\begin{array}{l}\text { Gold } \\
\text { combined with }\end{array}$} & \multirow{2}{*}{$\begin{array}{c}\text { Engle-Granger } \\
\text { Test ADF } \\
{[p \text {-value }]}\end{array}$} & \multicolumn{4}{|c|}{ Johansen Test [ $p$-value] } \\
\hline & & & $\begin{array}{c}\text { rank } \\
\mathrm{r}\end{array}$ & Eigenvalue & Trace Statistic & $\begin{array}{c}\text { Max-Eigen } \\
\text { Statistic }\end{array}$ \\
\hline \multirow{2}{*}{1} & \multirow{2}{*}{ LBUSTRUU } & \multirow{2}{*}{$\begin{array}{c}-2.75293 \\
{[0.1811]}\end{array}$} & 0 & 0.02576 & $\begin{array}{c}9.1315 \\
{[0.3599]}\end{array}$ & $\begin{array}{c}6.6118 \\
{[0.5440]}\end{array}$ \\
\hline & & & 1 & 0.00991 & $\begin{array}{c}2.5197 \\
{[0.1124]}\end{array}$ & $\begin{array}{c}2.5197 \\
{[0.1124]}\end{array}$ \\
\hline \multirow{2}{*}{2} & \multirow{2}{*}{ S\&P500 } & \multirow{2}{*}{$\begin{array}{c}-1.04504 \\
{[0.8932]}\end{array}$} & 0 & 0.02420 & $\begin{array}{c}7.7086 \\
{[0.5042]}\end{array}$ & $\begin{array}{c}6.1976 \\
{[0.5947]}\end{array}$ \\
\hline & & & 1 & 0.00595 & $\begin{array}{c}1.5110 \\
{[0.2190]}\end{array}$ & $\begin{array}{c}1.5110 \\
{[0.2190]}\end{array}$ \\
\hline \multirow{2}{*}{3} & \multirow{2}{*}{ WILREIT } & \multirow{2}{*}{$\begin{array}{c}-1.75108 \\
{[0.6541]}\end{array}$} & 0 & 0.01105 & $\begin{array}{c}3.7842 \\
{[0.9132]}\end{array}$ & $\begin{array}{c}2.8105 \\
{[0.9482]}\end{array}$ \\
\hline & & & 1 & 0.00384 & $\begin{array}{c}0.9737 \\
{[0.3238]}\end{array}$ & $\begin{array}{c}0.9737 \\
{[0.3238]}\end{array}$ \\
\hline
\end{tabular}

Source: own work based on (World Gold Council [WGC], n.d.; Bloomberg, n.d.; Wilshire Associates, n.d.; Yahoo Finance, n.d.; YCharts, n.d.).

With respect to them, the Granger causality test was carried out using the VAR model, based on variable increments without error correction, given the identified non-stationary character of the variables and the zero-order matrix $\Pi(r=0)$. The 
first logarithmic increments of the variables corresponded to the logarithmic rates of return on investments $(\mathrm{R})$ in the selected assets (stocks, bonds, and real estate), and physical gold.

Given the stationary character of these variables, as already proven, no spurious correlation could occur. The correlation coefficients between the analysed rates of return are shown in Table 4.

Table 4. Pearson's correlation coefficients between the analysed rates of returns

\begin{tabular}{|c|l|c|c|}
\hline I & \multicolumn{1}{|c|}{ Rates of return } & Correlation coefficient & $p$-value \\
\hline 1 & R_LBUSTRUU, R_GOLD & $0.2734^{*}$ & $<0.0001$ \\
\hline 2 & R_S\&P500, R_GOLD & 0.0069 & 0.91090 \\
\hline 3 & R_WILREIT, R_GOLD & $0.1081^{* * *}$ & 0.07960 \\
\hline 4 & R_LBUSTRUU, R_WILREIT & $0.1798^{*}$ & 0.00340 \\
\hline 5 & R_S\&P500, R_WILREIT & $0.5711^{*}$ & $<0.0001$ \\
\hline 6 & R_LBUSTRUU, R_S\&P500 & -0.0487 & 0.43090 \\
\hline
\end{tabular}

$\mathrm{H} 0$ is rejected for the significance level: ${ }^{*} \alpha=0.01 ; * * \alpha=0.05 ; * * * \alpha=0.1$

Source: own work based on (World Gold Council [WGC], n.d.; Bloomberg, n.d.; Wilshire Associates, n.d.; Yahoo Finance, n.d.; YCharts, n.d.).

As shown in Table 4, not all the results were statistically significant. A statistically significant linear relationship between the rates of return on investments in the analysed assets was found only for S\&P and WILREIT (moderate correlation), and for LBUSTRUU and GOLD (weak correlation), with the same significance level $(\alpha=0.01)$. In other cases, the correlation was extremely low (WILREIT and GOLD, $\alpha=0.1$; LBUSTRUU and WILREIT, $\alpha=0.01$ ).

The number of lags for VAR models was determined using the Akaike information criterion (AIC), the Bayesian information criterion (BIC), and the Hannan-Quinn information criterion (HQC), as presented in Table 5. Based on BIC and HQC, 1 lag was considered optimal for the VAR(1) model estimates. As regards AIC, the VAR(2) and VAR(6) models were additionally taken into account for the respective markets.

Table 5. The optimal number of lags for VAR models by information criterion

\begin{tabular}{|c|l|c|c|c|}
\hline \multirow{2}{*}{ Model } & \multicolumn{2}{|c|}{ Variables } & \multicolumn{3}{|c|}{ Number of lags [information criterion value $]$} \\
\cline { 3 - 5 } & & AIC & BIC & HQC \\
\hline 1 & R_GOLD; R_LBUSTRUU & $2[-9.707630]^{*}$ & $1[-9.619363]^{*}$ & $1[-9.671318]^{*}$ \\
\hline 2 & R_GOLD; R_S\&P500 & $1[-6.672803]^{*}$ & $1[-6.585787]^{*}$ & $1[-6.637742]^{*}$ \\
\hline 3 & R_GOLD; R_WILREIT & $6[-5.970249]^{*}$ & $1[-5.845104]^{*}$ & $1[-5.895324]^{*}$ \\
\hline
\end{tabular}

* Optimal number of lags.

Source: own work based on (World Gold Council [WGC], n.d.; Bloomberg, n.d.; Wilshire Associates, n.d.; Yahoo Finance, n.d.; YCharts, n.d.). 
Table 6 features the results of the overall parameter significance test and the Doornik-Hansen test (for a normal distribution of residuals) for the estimated models.

Table 6. The results of the F-test for the overall significance of VAR model parameters and the Doornik-Hansen residual normality test

\begin{tabular}{|c|c|c|c|}
\hline I & Null hypothesis & F-test [ $p$-value $]$ & Normality test [ $p$-value $]^{\text {a) }}$ \\
\hline \multirow[t]{2}{*}{1} & R_GOLD $\nrightarrow$ R_LBUSTRUU & $\begin{array}{l}\operatorname{VAR}(1): 0.66804[0.4145] ; \\
\operatorname{VAR}(2): 0.45590[0.6344]\end{array}$ & 12.4302 [0.00199899] \\
\hline & R_LBUSTRUU $\nrightarrow$ R_GOLD & $\begin{array}{l}\operatorname{VAR}(1): 3.4943[0.0627]^{* * *} \\
\operatorname{VAR}(2): 3.0903[0.0472]^{* *}\end{array}$ & $9.64998[0.00802662]$ \\
\hline \multirow[t]{2}{*}{2} & R_GOLD $\nrightarrow$ R_S\&P500 & $\operatorname{VAR}(1): 1.7670$ [0.1849] & $20.8091\left[3.02936 \times 10^{-5}\right]$ \\
\hline & R_S\&P500 $\nrightarrow$ R_GOLD & $\operatorname{VAR}(1): 0.66241$ [0.4165] & $16.103[0.000318616]$ \\
\hline \multirow[t]{2}{*}{3} & R_GOLD $\nrightarrow$ R_WILREIT & $\begin{array}{l}\operatorname{VAR}(1): 2.5933[0.1085] ; \\
\operatorname{VAR}(6): 1.8127[0.0971]^{* * *}\end{array}$ & $113.931\left[1.8208 \times 10^{-25}\right]$ \\
\hline & R_WILREIT $\nrightarrow$ R_GOLD & $\begin{array}{l}\text { VAR(1): } 0.036434[0.8488] \text {; } \\
\text { VAR6): } 0.49031[0.8153]\end{array}$ & $14.1406[0.000849966]$ \\
\hline
\end{tabular}

$\mathrm{H} 0$ is rejected for the significance level: ** $\alpha=0.05 ; * * * \alpha=0,1$; ${ }^{\text {a) }}$ for $\operatorname{VAR}(1)$ models

Source: own work based on (World Gold Council [WGC], n.d.; Bloomberg, n.d.; Wilshire Associates, n.d.; Yahoo Finance, n.d.; YCharts, n.d.).

The Granger test results for the VAR(1) models (Models 1, 2 and 3), concerning investments in gold and selected groups of assets, were varied. For Model 1, unidirectional interdependence from the rates of return on bonds to gold was found to exist at the significance level of $\alpha=0.1$, with no reverse relation being observed. As regards Model 1 with two lags, VAR(2), estimated on the basis of AIC, the rates of return on bonds are also Granger-caused gold. The null hypothesis was rejected at the significance level of $\alpha=0,05 ; \mathrm{F}(2,257)=3.0903$ [0.0472]**. Moreover, the result for a contradictory relationship was confirmed, as there were no grounds for rejecting the null hypothesis of the absence of causality from the rates of return on gold to bonds: $F(2,257)=0.45590$ [0.6344]. The analysis of the relationship between the gold and stock markets (Model 2) was carried out only on the basis of the VAR(1) model, given the consistency of the number of lags for all the information criteria. As a consequence, no causality was revealed between the rates of return in any direction. The results obtained for VAR(1) Model 3 revealed the absence of Granger causality from the rate of return on gold to the real estate market, and vice versa, assuming the standard level of significance $(\alpha=0.1)$. However, as regards VAR(6) Model 3, unidirectional causality from the rates of return on gold to real estate was the only causal relation detected. Model residuals were not normally distributed. 


\subsection{An analysis of forecast error variance decomposition}

The above deliberations indicate that Granger causality between the analysed variables was relatively rare. With a view to verifying the obtained research result an analysis of forecast variance decomposition was carried out.

Tables 7, 8, and 9 show the error variance decomposition results for a 24-month forecast period for various VAR(1) type models, estimated on the basis of the rates of return for indices $\left(y_{t}\right)$ and gold $(z)$, taking into consideration various orders of model variables. In terms of assessing the relations between these variables, it appears of the highest importance to correctly interpret the last period (the bottom lines in the tables).

Table 7. Forecast error variance decomposition for Model 1 (R_GOLD; R_LBUSTRUU)

\begin{tabular}{|l|c|c|c|c|c|c|c|c|}
\hline \multirow{3}{*}{$\begin{array}{c}\text { Forecasting } \\
\text { horizon } \\
\text { (month) }\end{array}$} & \multicolumn{4}{|c|}{ Ordering of variables: $y_{t}, z_{t}$} & \multicolumn{3}{c|}{ Ordering of variables: $z_{t}, y_{t}$} \\
\cline { 2 - 10 } & \multicolumn{2}{|c|}{ R_LBUSTRUU } & \multicolumn{2}{c|}{ R_GOLD } & \multicolumn{2}{c|}{ R_LBUSTRUU } & \multicolumn{2}{c|}{ R_GOLD } \\
\cline { 2 - 9 } & \multicolumn{2}{|c|}{ percent of variance due to the shocks } & \multicolumn{2}{c|}{ percent of variance due to the shocks } \\
\cline { 2 - 9 } & LBSTR. $^{*}$ & GOLD & LBSTR. & GOLD & LBSTR. & GOLD & LBSTR. & GOLD \\
\hline 1 & 100.00 & 0.000 & 7.080 & 92.920 & 92.920 & 7.080 & 0.000 & 100.00 \\
\hline 2 & 99.753 & 0.247 & 7.511 & 92.489 & 92.876 & 7.124 & 1.312 & 98.688 \\
\hline $5-24$ & 99.751 & 0.249 & 7.511 & 92.489 & 92.875 & 7.125 & 1.319 & 98.682 \\
\hline
\end{tabular}

* LBSTR. - LBUSTRUU.

Source: own work based on (World Gold Council [WGC], n.d.; Bloomberg, n.d.; Wilshire Associates, n.d.; Yahoo Finance, n.d.; YCharts, n.d.).

Table 7 shows that, for the order of variables $y_{t}, z$, the variable R_LBUSTRUU in the initial period was entirely (100\%) self-generated, and did not depend on the other variable (gold), whereas the variable R_GOLD was $92.92 \%$ self-generated. In the subsequent period the components of variance of both variables stabilised. In the last period (the bottom line in the Table), the variable R_LBUSTRUU was $99.75 \%$ self- generated, and influenced variable R_GOLD in $7.51 \%$ (in other words, the variable R_GOLD depended on the bond index R_LBUSTRUU to this extent), whereas the variable LBUSTRUU only $0.23 \%$ depended on gold. Given that the VAR model residuals displayed moderate correlations (Pearson's correlation coefficients $=0.27, p$-value $<0.0001$ ), an analysis was also carried out after changing the order of equations $\left(z_{t}, y_{t}\right)$. The obtained results were found to differ from the previous ones, however a slight impact of R_LBUSTRUU on R_GOLD (1.32\%) could still be noted. On this basis the variable R_LBUSTRUU should be treated as a priority variable, as it was more independent of gold than the other way round. This result was confirmed by the Granger causality analysis (unidirectional causality from R_LBUSTRUU, and no causality in the reverse direction, Model 1). 
Table 8. Forecast error variance decomposition for Model 2 (R_GOLD; R_S\&P500)

\begin{tabular}{|l|c|c|c|c|c|c|c|c|}
\hline \multirow{3}{*}{$\begin{array}{c}\text { Forecasting } \\
\text { horizon } \\
\text { (month) }\end{array}$} & \multicolumn{4}{|c|}{ Ordering of variables: $y_{t}, z_{t}$} & \multicolumn{3}{c|}{ Ordering of variables: $z_{t}, y_{t}$} \\
\cline { 2 - 9 } & \multicolumn{2}{|c|}{ R_S\&P500 } & \multicolumn{2}{|c|}{ R_GOLD } & \multicolumn{2}{c|}{ R_S\&P500 } & \multicolumn{2}{|c|}{ R_GOLD } \\
\cline { 2 - 9 } & \multicolumn{2}{|c|}{ percent of variance due to the shocks } & \multicolumn{2}{c|}{ percent of variance due to the shocks } \\
\cline { 2 - 9 } & S\&P500 & GOLD & S\&P500 & GOLD & S\&P500 & GOLD & S\&P500 & GOLD \\
\hline 1 & 100.00 & 0.000 & 0.007 & 99.993 & 99.993 & 0.007 & 0.000 & 100.00 \\
\hline 2 & 99.344 & 0.657 & 0.268 & 99.732 & 99.347 & 0.653 & 0.251 & 99.749 \\
\hline $5-24$ & 99.342 & 0.658 & 0.269 & 99.732 & 99.346 & 0.654 & 0.252 & 99.749 \\
\hline
\end{tabular}

Source: own work based on (World Gold Council [WGC], n.d.; Bloomberg, n.d.; Wilshire Associates, n.d.; Yahoo Finance, n.d.; YCharts, n.d.).

Table 8 reveals that a changed order of equations did not materially influence the obtained results (line 24: $99.342 \%$ versus $99.346 \%$ for R_S\&P500, and $99.732 \%$ versus $99.749 \%$ for R_GOLD). Therefore, one might rightly infer that the random elements were not correlated $\left(\rho_{12}=0.008, p\right.$-value $\left.=0.8925\right)$, i.e. the order of equations was not as important as in the case of the strongly correlated elements. In addition, both variables R_S\&P500 (99.342\% and 99.346\%) and R_GOLD (99.732\% and $99.749 \%$ ) were independent of the equations' order, being almost entirely self-generating. This finding was consistent with the results of the Granger test, revealing the absence of causality between these variables (Model 2).

Table 9. Forecast error variance decomposition for Model 3 (R_GOLD; R_WILREIT)

\begin{tabular}{|l|c|c|c|c|c|c|c|c|}
\hline \multirow{3}{*}{$\begin{array}{c}\text { Forecasting } \\
\text { horizon } \\
\text { (month) }\end{array}$} & \multicolumn{4}{|c|}{ Ordering of variables: $y_{t} z_{t}$} & \multicolumn{3}{c|}{ Ordering of variables: $z_{t^{\prime}} y_{t}$} \\
\cline { 2 - 9 } & \multicolumn{2}{|c|}{ R_WILREIT } & \multicolumn{2}{c|}{ R_GOLD } & \multicolumn{2}{c|}{ R_WILREIT } & \multicolumn{2}{c|}{ R_GOLD } \\
\cline { 2 - 9 } & \multicolumn{2}{|c|}{ percent of variance due to the shocks } & \multicolumn{2}{c|}{ percent of variance due to the shocks } \\
\cline { 2 - 9 } & WREIT* & GOLD & WREIT & GOLD & WREIT & GOLD & WREIT & GOLD \\
\hline 1 & 100.000 & 0.000 & 0.960 & 99.040 & 99.040 & 0.960 & 0.000 & 100.000 \\
\hline 2 & 99.032 & 0.968 & 0.946 & 99.054 & 98.215 & 1.785 & 0.014 & 99.986 \\
\hline $5-24$ & 99.030 & 0.970 & 0.946 & 99.054 & 98.212 & 1.788 & 0.014 & 99.986 \\
\hline
\end{tabular}

* WREIT - WILREIT.

Source: own work based on (World Gold Council [WGC], n.d.; Bloomberg, n.d.; Wilshire Associates, n.d.; Yahoo Finance, n.d.; YCharts, n.d.).

As shown in Table 9, after changing the order of equations, the obtained results were only slightly different. Variable R_WILREIT became slightly more dependent on variable R_GOLD (1.788\% versus $0.970 \%)$, whereas variable R_GOLD became less dependent on variable R_WILREIT (0.014\% versus $0.946 \%)$. Apart from these two minor deviations, the research results did not differ significantly due to the order 
of equations. Therefore, one might rightly infer that the random elements were not correlated $\left(\rho_{12}=0.098, p\right.$-value $\left.=0.1130\right)$, and the variables were not interdependent, as also proven by the Granger test (the absence of causality, Model 3).

\section{Conclusion}

The direction of causality of the analysed variables reflects the fact that capital tends to move away from the gold market to the markets of more profitable assets, or to return to that market. The research by many authors mostly concerned the relationship between the gold market and the bond market, covering different periods and countries. Various research results indicate either unidirectional causality from bonds to gold or a reverse relation, or even no causality between these two. Causality from interest rates on investments in bonds to gold was also observed. The research presented in this article proves that, except in two cases of unidirectional causality (from bonds to gold and from gold to real estate), no causality in any direction was observed. This result was confirmed by testing the forecast error variance decomposition for Model 1 (the impact of bonds on gold). Except for the two cases mentioned, this implies that price changes occurring on the markets of the analysed assets did not impact on the decisions made by those investors who had put money into financial instruments of the underlying entities of those indices, nor did they determine changes to gold prices, and vice versa. Only in the cases of bonds did the rate of return on the markets of the analysed assets Granger-cause the rates of return on the gold market, with the standard level of confidence $\alpha=0.01$ since bonds and gold are relatively safe assets to invest in. In this respect, gold, which generates no interest, becomes a desirable investment alternative to bonds in periods of low interest rates. Except for one case (from bonds to gold), the research hypothesis that the ROR on the markets of the analysed assets Granger-caused the ROR on the gold market was negatively verified. The results of further research may be affected by the coronavirus pandemic which puts a negative pressure on financial markets around the world. There are still justified worries about the condition of the global economy (lockdown, unemployment, household and public debt). In these circumstances gold can be an attractive alternative investment besides the other financial assets such as stocks, real estate or bonds due to extremely low interest rates.

\section{References}

Acikalin, S., and Bayci, E. S. (2016). Cointegration and causality relationship between BIST 100 and BIST Gold Indices. Journal of Management and Economics, 23(2), 565-574.

Baur, D. G., and Lucey, B. M. (2010). Is gold a hedge or a safe haven? An analysis of stocks, bonds and gold. The Financial Review, 45, 217-229. doi: 10.1111/j.1540-6288.2010.00244.x

Bloomberg. (n.d.). Retrived March 22, 2019 from https://www.bloomberg.com/quote/LBUSTRUU:IND 
Bouri, E., Jain, A., Biswal, P. C., and Roubaud, D. (2017). Cointegration and nonlinear causality amongst gold, oil, and the Indian stock market: evidence from implied volatility indices. Resources Policy, 52, 201-206. doi: 10.1016/j.resourpol.2017.03.003

Charemza, W. W., and Deadman, D. F. (1997). Nowa ekonometria. Warszawa: PWE.

Enders, W. (2010) Applied econometric time series. Hoboken: Wiley \& Sons.

Fernandez-Perez, A., Frijns, B., and Tourani-Rad, A. (2017). Precious metals, oil and the exchange rate: contemporaneous spillovers. Applied Economics, 49(38), 3863-3879. doi: 10.1080/00036 846.2016 .1270416

Gujarati, D. N. (2003). Basic Econometrics. Boston: McGraw Hill.

Johansen, S., and Juselius, K. (1990). Maximum likelihood estimation and inference on cointegration with applications to the demand for money. Oxford Bulletin of Economics \& Statistic, 52(2), 169-210.

Kusideł, E. (2000). Modele wektorowo-autoregresyjne VAR. Metodologia i zastosowanie. Łódź: Absolwent.

Ling, T. He (1998). Cointegration and price discovery between equity and mortgage REITs. Journal of Real Estate Research, 16(3), 327-338.

Singh, D. (2014). Dynamics of gold prices, crude oil prices and stock index comovements: cointegration evidence of India. Finance India, 28(4), 1265-1274.

Singh, N. P., and Sharma, S. (2018). Cointegration and causality among dollar, oil, gold and sensex across global financial crisis. Vision, 22(4), 365-376. doi:10.1177/0972262918804336

Steiner, M., and Bruns, C. (1996), Wertpapiermanagement, Stuttgart: Schäffer Poeschel Verlag.

Sujit, K. S., and Kumar Rajesh, B. (2011). Study on dynamic relationship among gold price, oil price, exchange rate and stock market returns. International Journal of Applied Business and Economic Research, 9(2), 145-165.

Tursoy, T., and Faisal, F. (2018). The impact of gold and crude oil prices on stock market in Turkey: empirical evidence from ARDL bounds test and combined cointegration. Resources Policy, 55, 49-54. doi: 10.1016/j.resourpol.2017.10.014

Wang, Y. S., and Chueh, Y. L. (2013). Dynamic transmission effects between the interest rate, the US dollar, and gold and crude oil prices. Economic Modelling, 30, 792-798. doi: 10.1016/j.econmod.2012.09.052.

Wilshire Associates. (n.d.). Retrived March 22, 2019 from https://wilshire.com/indexcalculator/index. html\#

World Gold Council. (n.d.). Retrived March 22, 2019 from https://www.gold.org/

Yahoo Finance. (n.d.). Retrived March 22, 2019 from https://finance.yahoo.com/

YCharts. (n.d.). Retrived March 22, 2019 from https://ycharts.com/indices/\%5EBBUSATR/level

Zhang, Y-J., and Wei, Y-M. (2010). The crude oil market and the gold market: evidence for cointegration, causality and price discovery, Resources Policy, 35(3), 168-177. doi: 10.1016/j.resourpol.2010.05.003

\section{ANALIZA PRZYCZYNOWOŚCI MIĘDZY ZŁOTEM I WYBRANYMI KLASAMI AKTYWÓW}

Streszczenie: Złoto należy do aktywów nisko lub ujemnie skorelowanych z rynkami podstawowych aktywów finansowych i może stanowić alternatywną formę lokaty kapitału. Istotne stają się ocena wpływu tych rynków na rynek (cenę) złota oraz ich wzajemne relacje. Decyzje inwestorów o alokacji kapitału na wymienionych rynkach określają rodzaj i kierunek przyczynowości tych aktywów. Celem artykułu jest ocena zależności przyczynowych między stopami zwrotu z inwestycji w złoto i w następujące aktywa: akcje, obligacje i nieruchomości, reprezentowane przez odpowiadające im indeksy 
giełdowe. Badania obejmują lata 1997-2018. W analizie posłużono się modelem VAR, stanowiącym podstawę do zastosowania testu liniowego nie-przyczynowości Grangera oraz dekompozycji wariancji. Poza dwoma przypadkami jednostronnej przyczynowości: od stóp zwrotu z obligacji do złota i od stóp zwrotu ze złota do nieruchomości nie stwierdzono innych rodzajów przyczynowości. Pomijając te sytuacje, oznacza to, że zmiany ceny złota nie wpływały na decyzje inwestorów, angażujących kapitały na pozostałych rynkach badanych aktywów i odwrotnie.

Słowa kluczowe: rynki akcji, obligacji i nieruchomości, cena złota, modele VAR, przyczynowość Grangera. 